\title{
EVALUATION OF THE DOMESTICATION PROCESS IN SERBIA - DOMESTICATION OF NEOLITHIC CATTLE
}

\author{
JOVANOVIĆ S*, SAVIĆ MILA*, TRAILOVIĆ RUŽICA*, JANKOVIĆ Ž and ŠLJIVAR D** \\ *Faculty of Veterinary Medicine, Belgrade; *National Museum, Belgrade
}

(Received 11. August 2004)

The neolithic settlement Belovode, situated between the two important centres of prehistoric culture: Vinča and Rudna Glava has been only partly investigated. In this study, the Belovode zoological collection was examined with the aim of providing data concerning the character of domesticated and transitional animals and wild ancestral forms inhabiting the Central Balkans during neolithic times.

A total of 3487 animal bone fragments have been excavated at the site, so far. It was established that the bone remnants chronologically belong to the period of about 5500 - 4800 years B.C. by radiocarbon dating. Morphological comparison showed that almost $42 \%$ of the bone remnants were of bovine origin. In order to define the character of the domesticated or wild ancestors of cattle in East Serbia at that time, the bovine collection was further examined in detail. The total of 18 horns/horn bases allowed morphological comparison and morphometric analysis. The data obtained showed that two different ancestors of domesticated cattle were exploited in Belovode: Bos primigenius and Bos brachyceros. Among the archaeological findings were zoomorphic figurines including ox sculptures the shape and details of wich also indicated cattle farming activity in neolithic Belovode.

Key words: domestication, neolithic, Bos primigenius, Bos brachyceros

\section{INTRODUCTION}

Agriculture came to central Europe over 7000 years ago, but the existing archaeological records do not allow a complete chronological interpretation (Bogucki, 1995). Most of the data point to development of communities in the area from the middle Danube valley (territories of Austria, Hungary and Slovakia) to the north reaching the rivers Vistula and Oder and to the west reaching the Paris basin. It is widely accepted that farming was introduced to Central Europe from South-Eastern Europe and ultimately from the Near East.

Neolithic civilization centres, situated on the banks of the Danube in the Balkan Peninsula share a unique degree of developed society. Thus, welldeveloped pastoral communities have been described in Vinča, Selevac and 
Divostin, all situated on the banks of the Danube (Bökönyi, 1974, 1988; Legge, 1990, Clason, 1979).

Animal bone remnants have been excavated in all the most studied neolithic settlements situated in the south ridge of the Pannonian Basin, in Serbia (Bökönyi, 1988). Studies of the domesticated fauna along the south ridge of the Pannonian basin were expected to provide evidence about the introduction of domestic animals into Central Europe, as in case of Starčevo, and data concerning the development of locally based European animal husbandry, characteristic for Vinča (Bökönyi, 1968). The process of demoid diffusion of farming from the Far East to Central and North Europe has been evaluated and evidence connecting the farming communities from Asia to Greece and those in Central and North Europe has been presented. These findings indicate the mechanism of "Farming transmission" throughout the neolithic populations of Central Europe (Bogucki, 1995). The connections linking distant centres of neolithic culture in Europe with those in the Near East and further with Eurasia are only partly documented and new data from the Central Balkans can provide information concerning the dispersal of cultural traits and domestic animal heritage.

Evaluation of the archaeological site of Belovode, situated between the two important centres of neolithic culture: Vinča and Rudna Glava, revealed cultural links connecting the two well-explored centres. Some excavated metalwork indicated cultural links leading to the distant neolithic cultures in Asia (Šljivar, 1996). However, investigations at the site were restricted to only $10 \%$ of the territory of the settlement and numerous bone remnants were obtained.

A total of 3487 animal bone pieces have been excavated at the Belovode site, so far. Radiocarbon dating defined chronologically that the collected bone fragments belonged to the period from $5500-4800$ years B.C. Their morphology revealed that a large proportion (42\%) was of bovine origin (Jovanović et al., 2003).

Unfortunately whole skulls and large skull fragments are rare in the material yielded so far. Nevertheless some horn fragments with or without the horn base were found and the condition of the artefacts allowed speciation. Having in mind that cattle horn bases are very informative for differentiating between domesticated and wild ancestors of this domestic animal, and the development of cattle breeding through transmition from one early human societie to unother, the aim of this work was evaluation of the excavated horn bases of bovine origin.

\section{MATERIAL AND METHODS}

Bone fragments excavated at the site of the neolithic settlement, Belovode, were analysed by morphological comparison and chronologically tested by radiocarbon dating.

Horn remnants excavated at the site of Belovode and suitable for differentiation of the species were also included in the evaluation.

Basal sections of bovine horn cores with or without the anterior section of frontals were analysed. The total number of specimens, was noted. Differentiation of the species was performed by morphological comparison. 
Acta Veterinaria (Beograd), Vol. 54, No. 5-6, 467-473, 2004.

The maximal and minimal diameter of the horn core bases and maximal circumference of the base were measured by a standard morphometric procedure.

Collection of well-preserved zoomorphic figurines helped in the differentiation of domesticated animals from those undergoing domestication.

\section{RESULTS AND DISCUSSION}

A total of 18 horn bases were present in the Belovode bone collection. Morphology revealed that the horn fragments excavated belonged to cattle (9), the capra/ovis group (4), red deer (3) and roe deer (1), as shown in Table 1. The bovine horn fragments were further differentiated as Bos primigenius (auroch) and Bos brachyceros remnants (Figure 1). The small proportion of horn fragments in the bone collection may be viewed from an anthropological point. Neolithic man used horns for different activities, such as cults, religion and toolwork (Garašanin, 1968).

Table 1. Horn fragments identified at Belovode site

\begin{tabular}{|c|c|c|c|c|}
\hline Species & No fragments & $\begin{array}{c}\text { No of whole } \\
\text { horns }\end{array}$ & $\begin{array}{c}\text { No of horn base } \\
\text { with base skull } \\
\text { fragments }\end{array}$ & $\begin{array}{c}\text { Percent in total } \\
\text { collection }\end{array}$ \\
\hline \hline Bos primigenius & 7 & 0 & 6 & 0.20 \\
\hline $\begin{array}{c}\text { Bos brachyc- } \\
\text { eros }\end{array}$ & 2 & 0 & 1 & 0.06 \\
\hline $\begin{array}{c}\text { Capra-ovis } \\
\text { group }\end{array}$ & 4 & 1 & 2 & 0.11 \\
\hline $\begin{array}{c}\text { Capreolus ca- } \\
\text { preolus }\end{array}$ & 1 & 0 & 1 & 0.03 \\
\hline Cervus elaphus & 3 & 0 & 1 & 0.09 \\
\hline \hline \multicolumn{7}{|c|}{18} & & 0.573 \\
\hline
\end{tabular}

The dominating proportion of cattle bone remnants in the Belovode collection is in accordance with the finding that $50 \%$ of the total horn collection was of bovine origin. The finding of both Bos primigenius and Bos brachyceros horn fragments can be considered very informative.

Cross-sections of horn fragments originating from Bos primigenus are elliptical. The surface of the horn core fragments is ornamented by vascular foramina and shallow or deep longitudinally directed grooves. The morphometric parameters of the Bos primigenius horn remnants were compared to data from the literature (Table 2).

According to Zong, (1984) Bos primigenius descended from the South Asian taxon Bos Namadicus originating from Bos Planifrons which inhabited India and Pakistan in the early pleistocen. During the late quaternary, Bos primigenius 
became extensively distributed throughout Euroasia and North Africa. Cattle breeding in neolithic communities of Neolithic Europe could have arisen by mechanism of localized adoption of livestock by indigenous foraging people, but much evidence points to the mechanism of demoid diffusion of farming by sedentary communities from the southeast to the north and west of Europe (Bogucki, 1995). Therefore the finding of remnants of domesticated and cattle undergoing domestication on the Balkans gives some idea about the links connecting neolithic communities in different regions. Furthermore the Belovode collection was radio dated into the period preceding the findings in Central and North Europe.

Table. 2 Comparative horn core measurements of Bos primigenius and Bos brachyceros

\begin{tabular}{|c|c|c|c|c|c|}
\hline \multirow{3}{*}{ Parameter } & \multicolumn{5}{|c|}{ Excavation site } \\
\hline & \multirow{2}{*}{\begin{tabular}{|c|} 
Bos \\
brachyceros
\end{tabular}} & \multicolumn{4}{|c|}{ Bos primigenius } \\
\hline & & $\begin{array}{l}\text { Belovode } \\
\text { (mean mm) }\end{array}$ & $\begin{array}{c}\text { Gomolava** } \\
(\text { mean } \mathrm{mm})\end{array}$ & $\begin{array}{c}\text { Former* } \\
\text { USSR } \\
\text { (mean mm) }\end{array}$ & $\begin{array}{c}\mathrm{Aba}^{\star} \\
(\text { mean } \mathrm{mm})\end{array}$ \\
\hline $\begin{array}{l}\text { Maximal } \\
\text { diameter of } \\
\text { horn core } \\
\text { base }(\mathrm{mm}) \\
\end{array}$ & 49.5 & $\begin{array}{c}62.5 \\
\text { (R: } 57-73)\end{array}$ & $\begin{array}{c}67.25 \\
\text { (R: } 55-79.5)\end{array}$ & $\begin{array}{c}115.25 \\
\text { (R:98.5-132) }\end{array}$ & $\begin{array}{c}140.5 \\
(R: 133-148)\end{array}$ \\
\hline $\begin{array}{l}\text { Minimal } \\
\text { diameter of } \\
\text { horn core } \\
\text { base }(\mathrm{mm}) \\
\end{array}$ & 43.5 & $\begin{array}{c}46,5 \\
\text { (R: } 40-58)\end{array}$ & $\begin{array}{c}53 \\
\text { (R: 41.5-64.5) }\end{array}$ & $\begin{array}{c}92 \\
\text { (R: 79-105) }\end{array}$ & $\begin{array}{c}115.5 \\
\text { (R:109-122) }\end{array}$ \\
\hline $\begin{array}{l}\text { Maximal } \\
\text { circumference } \\
\text { of the base } \\
(\mathrm{mm})\end{array}$ & 148.7 & $\begin{array}{c}177.92 \\
\text { (R: } 152.5-207.5)\end{array}$ & $\begin{array}{c}196 \\
\text { (R: 162.5-230) }\end{array}$ & $\begin{array}{c}322 \\
\text { (R: } 275-370)\end{array}$ & $\begin{array}{c}412 \\
\text { (R:380-445) }\end{array}$ \\
\hline
\end{tabular}

* $\mathrm{R}=$ range

* The data of Zong, 1984

**The data of Legge, 1990

Bos brachyceros is another ancestral form of European humpless cattle differing from Bos primigenius upon size, body length, leg diameter and horn lenght. It evolved from original Bos primigenius during its expansion throughout the Mediterranean area and has been introduced by the Romans to the north and west provinces including the British islands. Cross-sections of Bos brachyceros horn fragments are oval, almost round, with fine vascular groves and foramina. The base is almost round. The metric parameters of Bos brachyceros horn bases are presented in Table 2.

Based upon the ossificated structure of the base and remains of the skull, all horn fragments examined belonged to the adult animals (Figure 1). Both left and 
Acta Veterinaria (Beograd), Vol. 54, No. 5-6, 467-473, 2004.

Jovanović $\mathrm{S}$ et al. Evaluation of the domestication process

in Serbia - domestication of Neolithic cattle

right horn bases originated from different animals. It can be assumed that the consumption of adults only indicates the cattle farming activity, since young animals would have been used for breeding. These finding are in accordance with archaeological observations concerning the activities and society development of neolithic communities. Furthermore, developing farming settlements were scattered throughout the Middle and Far East and also on the Balkan Peninsula during the Neolith. These findings are similar to those from Gomolava and Vinča (Bokonyi, 1968, 1974, 1988; Legge, 1990).

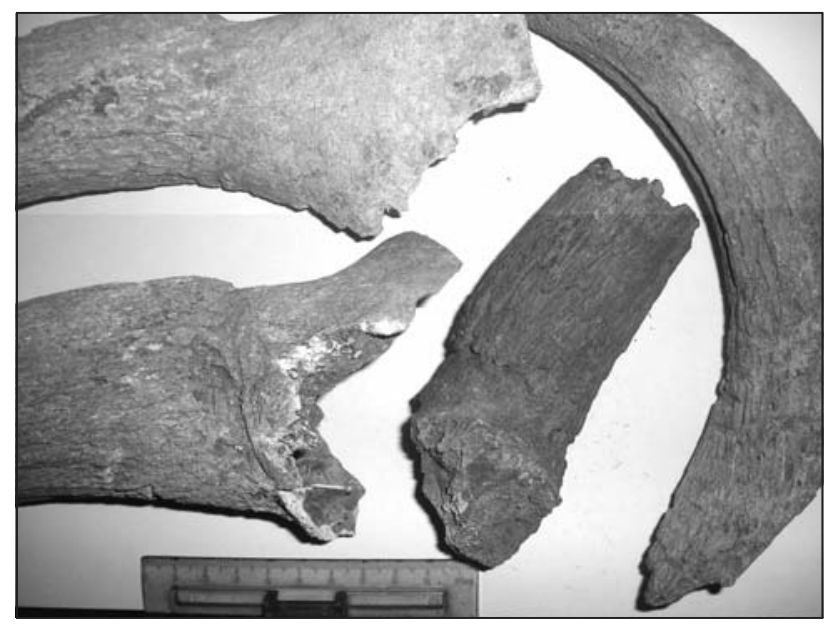

Figure 1. Bovine horn base fragments from Belovode

Many zoomorphic figurines were found within the house bases excavated on the site of the 6th test trench in Belovode. The ox figurines from Belovode can be considered among the most well preserved animal neolithic figurine collections discovered so far (Figure 2) and may be of great importance in the evaluation of domestication in the central Balkan region. The group consisted of two males, a cow and a calf. Body proportions were real and the sex characteristics of the sculptured animals were presented. On one male figurine lateral holes placed on the rostral part of the scull are clear. This finding points to possible restraining of cattle by humans in Belovode.

Morphological comparison of the excavated horn remnants showed that humans in Belovode exploited both Bos primigenius and Bos brachyceros.

Evaluation of the skull sutures revealed that all bovine horn bases in the Belovode collection belonged to adult animals.

The characteristics of the horn bases and figurines excavated at Belovode provide evidence for the existance of developed cattle breeding activity and leads to the conclusion that both ancestral forms of domestic cattle were domesticated 
or in transition during the period from $5500-4800$ years B.C. in Belovode. The archaeological artefacts: zoomorphic figurines also indicate cattle breeding activity. Woth the aim of establishing the purpose of the cattle it would be appropriate to evaluate the residual content of the excavated pots.

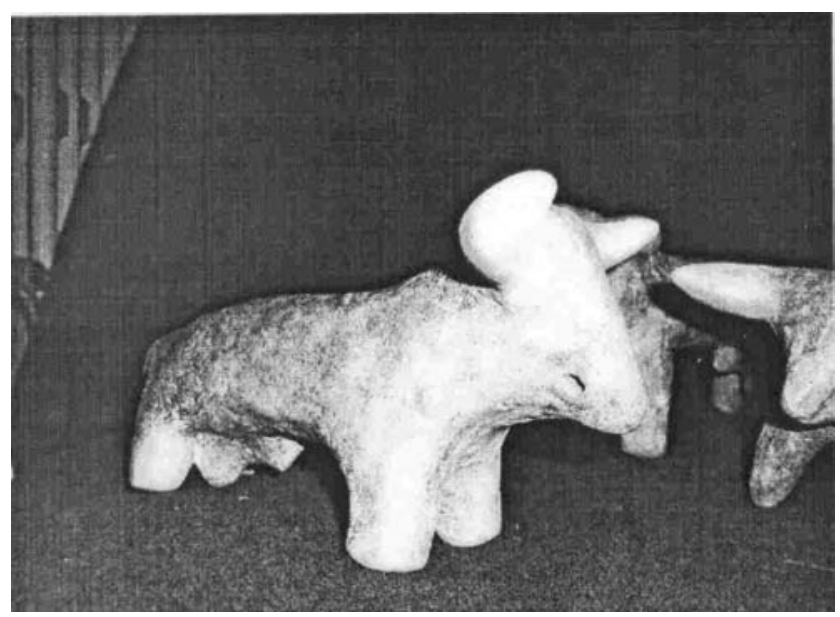

Figure 2. Figurine of anox, Belovode collection: visible: sex organs and rostral holes on the had (5 $500-4800$ years B.C)

ACKNOWLEDGEMENT:

This research was supported by Ministry of Science and technology, Republic of Serbia, grant 1830 .

Address for correspondence:

Slobodan Jovanović

Department of Animal Breeding and Genetics,

Faculty of Veterinary Medicine

Bul JNA 18, 11000 Belgrade,

Serbia \& Montenegro

e-mail: stocarstvo@vet.bg.ac.yu

\section{REFERENCES}

1. Bökönyi S, 1968, Die geschichtliche Entvicklung der Tierhaltung in Mittel und Osteuropa. Agrátörténeti Syemle 10, 277-342

2. Bökönyi S, 1974, History of domestic mammals of Central and Eastern Europe. In: The Neolithic Vertebrate Fauna, Budapest.

3. Bökönyi S, 1988, The Neolithic fauna of Divostin. In: Divostin and the Neolithic of central Serbia. Ed. Mc Pherron and Srejović D. Ethnology Monographs No 10, Pittsburgh, 419-55. 
Acta Veterinaria (Beograd), Vol. 54, No. 5-6, 467-473, 2004.

4. Bogucki P, 1995, How agriculture came to Central Europe. SAA paper, Annual Meeting for the Society for American Archaeology, Minneapolis.

5. Clason AT, 1979, The farmers of Gomolava in the Vinča and La Tene period. Rad vojvođanskih muzeja 25, Vojvođanski muzej, Novi Sad.

6. Garašanin D, 1968, Religija i kult neolitskog čoveka na centralnom Balkanu. In Neolit centralnog Balkana, Narodni muzej, Beograd, 241-63.

7. Jovanović S, Savić M, Trailović R, Janković Ž and Šljivar D, 2003, Evaluations of the domestication process in Serbia - Palezoological remnants at Neolithic settlement of Belovode. Acta Veterinaria, 53, 427-34.

8. Legge A.J, 1990, Animals, Economy and Environment in Selevac. A Neolithic village in Yugoslavia. Eds. Tringham R. and Krstić D, Los Angeles, 215-57.

9. Zong G, 1984, A record of Bos primigenius from the Quaternary of the Aba Tibetan Autonomous Region, Vertebrata PalAsiatica, 22, 3, 239-245.

10. Šljivar D, Jacanović D, 1996, Veliko Laole, Belovode-Vinča culture settlement in North-eastern Serbia, Prehistoire Europeenne, 8, 175-88.

\title{
PROUČAVANJE PROCESA DOMESTIKACIJE U SRBIJI - DOMESTIKACIJA GOVEDA U NEOLITU
}

\author{
JOVANOVIĆ S, SAVIĆ MILA, TRAILOVIĆ RUŽICA, JANKOVIĆ Ž i ŠLJIVAR D
}

\section{SADRŽAJ}

Neolitsko naselje Belovode, koje se nalazi između dva značajna preistorijska kulturna centra: Vinče i Rudne Glave je do sada samo delimično istraženo. Ispitivanje paleozoološke kolekcije dobijene dosadašnjim iskopavanjenjem Belovoda je sprovedeno sa ciljem da se utvrdi status domestikacije tokom neolita u Srbiji i Centralnom Balkanu i opišu odomaćeni i/ili divlji preci domaćih životinja.

Do sada je na nalazištu iskopano ukupno 3487 ostataka kostiju životinja. Procenjeno je da osteološki artefakti potiču iz perioda između 5500 i 4800 godina pre nove ere. Morfološkom analizom je utvrđeno da $42 \%$ ostataka kostiju potiče od goveda. U cilju boljeg poznavanja neolitskih predaka goveda na staništima istočne Srbije, preduzeto je istraživanje ostataka goveda metodom morfološke komparacije. Nalaz 18 rogova i baza rogova je omogućio veoma informativnu komparaciju i morfometrijske analizu. Dobijeni rezultati ukazuju da su u Belovodu bila zastupljena dva pretka domaćih goveda: Bos primigenius i Bos brachyceros. Arheološki nalaz zoomorfnih figurina, pre svega goveda, relnih oblika i izvajanih detalja takođe ukazuju na razvijeni uzgoj goveda u naselju Belovode. 